\title{
MEASURING CREATIVE ECONOMY IN INDONESIA: ISSUES AND CHALLENGES IN DATA COLLECTION
}

\author{
Eni Lestariningsih, Karmila Maharani and Titi Kanti Lestari ${ }^{*}$
}

\begin{abstract}
Although creative economy is emerging as an area to be evaluated, establishing a benchmark against which it can be measured is still problematic due to a range of definitional problems, both conceptual and practical. In recent years, many agencies and governments have invested significant effort into collecting data on creative economy, but in many countries, including Indonesia, measuring creative economy remains a challenge. Data collection on creative economy has been conducted twice in Indonesia, initially through surveys undertaken in 2016 and then in a compilation of the 2016 Economic Census. The data collection used a common classification system to identify the five-digit Indonesia Standard Industrial Classification (KBLI) regarded as creative economy. Out of a total of 1,573 five-digit KBLI codes, there are 223 which are identified as creative economy activities. However, this approach remains unstandardized in terms of concept definitions, data collection procedures, methods of analysis and common classification systems. This paper highlights the numerous limitations in current creative economy measurement in Indonesia, identifying issues and challenges in data collection and creative economy measurement processes that are needed to support the Sustainable Development Goals.
\end{abstract}

JEL classification: 010

Keywords: creative economy, Sustainable Development Goals

* Eni Lestariningsih, Statistics Indonesia, Badan Pusat Statistik, Jakarta, Indonesia (email:elen@bps.go.id). Karmila Maharani (email:karmila@bps.go.id); Titi Kanti Lestari (email:titi@bps.go.id). 


\section{INTRODUCTION}

Culture, innovation and creativity are now acknowledged as driving forces of the new economy. Organizations and even economic regions that embrace creativity generate significantly higher revenue and provide greater stability for the future. According to UNESCO, creative economy is "one of the most rapidly growing sectors of the world economy and a highly transformative one in terms of income generation, job creation and export earnings" (UNDP and UNESCO, 2013, p. 10). Creative economy sectors can contribute considerably to growth and prosperity, especially for developing countries seeking to diversify their economies and build resilience.

It is therefore essential to measure creative economy and its impact on the overall economic system, and the collection of quality statistics is critical to achieving the associated targets of the Sustainable Development Goals (SDGs). The central aim of the SDGs is to leave no one behind. They encompass the interlinkages among the three dimensions of economic growth, social development and environmental sustainability (Lestariningsih, Gusnisa and Maharani, 2017). The measurement of creative economy will thus enable evidence-based policymaking to support the SDGs.

Providing creative economy statistics undoubtedly requires extended processes and standardized procedures. As the importance of creative economy is increasingly appreciated, the necessity for quantifying its value and comparability is also growing. As stated by the World Economic Forum "the economic significance of the creative economy is indisputable; however, its impact is broader than can be measured simply by economic output" (World Economic Forum, 2016, p. 10).

The complexity of establishing criteria to measure creative economy is due to a range of conceptual and practical codification issues. Lack of standardization regarding definitions, data collection procedures, analysis and dissemination of data, and common classification systems all make regional comparison problematic.

Creative economy has become the new source of economic growth in Indonesia, but it requires unambiguous methods of evaluation in order to provide good quality data. It is anticipated that measurement of creative economy by survey will become more systematic and more accurate, following the life cycle survey, consisting of client liaison, planning, survey development, sample design, data processing, estimation, analysis, dissemination and evaluation. There are, however, still many hurdles to overcome in measuring the creative economy in Indonesia, and initially there is need for a framework, with standardization of concept and methodology in order to explore current insights for evidence of contribution towards sustainable development. 
This study highlights numerous limitations in current creative economy measurement practices in Indonesia, as well as the issues and challenges arising out of the collection of data and the development of a creative economy contribution model as an evidence base to support the Sustainable Development Goals.

\section{CREATIVE ECONOMY: CONCEPTS AND IMPORTANCE TO DEVELOPMENT}

Creative economy has become an economic growth booster in many countries, and is unique in that it is created from an unlimited resource - ideas. Not only is the resource unlimited, it also contributes high added value to goods and services. The United Kingdom Department for Digital, Culture, Media and Sport defined creative economy as "those industries which have their origin in individual creativity, skill and talent, and which have a potential for wealth and job creation through the generation and exploitation of intellectual property" (United Kingdom, Department for Digital, Culture, Media and Sport, 2001, p. 4).

Another definition of creative economy is provided by UNCTAD: "creative economy is an emerging concept dealing with the interface between creativity, heritage, economics and technology in a contemporary world dominated by images, sounds, texts and symbols" (UNCTAD, 2018). This definition emphasizes four determinants of creative economy: creativity, heritage, economics and technology.

In addition to boosting growth, creative economy contributes to sustainable development. It is becoming increasingly accepted that "sustainability" has a broader scope beyond its application to the environment. It is related to both tangible and intangible cultural capital, as part of creative economy, which is related to sustainable development (UNCTAD, 2010). Cultural sustainability implies a development process that maintains all types of cultural assets, from minority languages and traditional rituals to artworks, artefacts and heritage buildings and sites. It is creative industries that provide the services and investments necessary for culturally sustainable development paths to be followed. It includes industries related to creativity, art and culture, whose contribution can be characterized based on creative economy macroeconomic indicators, social culture development and environmental sustainability.

The development of creative economy has contributed to the United Nations Sustainable Development Goals, in particular: Goal 1 - "Eradicate extreme poverty for all people everywhere"; Goal 8 - "Promote sustained, inclusive and sustainable economic growth, full and productive employment and decent work for all"; and Goal 9 - "Build resilient infrastructure, promote inclusive and sustainable industrialization and foster innovation" (UNDP, 2015, pp. 10, 12). 
In this case, the essence of Goal 1 can be achieved through social and cultural elements, such as education, health and gender empowerment activities, which are closely related to poverty eradication. For example, an improvement in creative economy could enable an increase in living standards, translating into a higher proportion of the population living above the poverty line, as reflected in indicator 1.2.1 (proportion of population living below the national poverty line, by sex and age). Many creative economy activities emerge from young people, and observations have shown that many entrepreneurs are women.

For Goal 8 (sustainable economic growth), there are three indicators related to the development of creative economy, they are: 8.1.1 (annual growth rate of real gross domestic product per capita); 8.3 .1 (proportion of informal employment in non-agricultural occupations, by gender); and 8.9.2 (number of jobs in tourism industries as a proportion of total jobs and growth rate of jobs, by gender). These three indicators show that a developing creative economy will raise gross domestic product (GDP) per capita, absorb a greater number of informal ${ }^{1}$ employees and generate more jobs in creative fields related to tourism.

The measurement of innovation indicators can also be linked to Goal 9 (build resilient infrastructure, promote inclusive and sustainable industrialization and foster innovation). Creativity is one of the main criteria in research and development, especially in Target 9.5: enhance scientific research, upgrade the technological capabilities of industrial sectors in all countries, particularly developing countries including, by 2030, encouraging innovation and substantially increasing the number of workers and spending on both public and private research and development. Here, there are two relevant indicators: Indicator 9.5.1 - "Research and development expenditure as a proportion of GDP"; Indicator 9.5.2 - "Researchers (in full-time equivalent) per million inhabitants". More expenditure and researchers will thus result in more innovative products, goods and services.

\section{MEASURING THE CREATIVE ECONOMY IN INDONESIA: METHODOLOGY, RESULTS, AND SYNTHESIS}

Many countries have collected data on creative economy, particularly: Australia (surveys of industries); Canada (Culture labour-force survey, Statistics Canada); Finland, France and Italy (creative sector statistics collected, national statistical agencies); the Philippines (extracts from national statistical agency); and the United Kingdom and Singapore (extracts of information from data collected by businesses at 4-5 digit

Informal employees include: (1) self-employment, (2) temporary workers / unpaid labourers, (3) free workers in agriculture, (4) free workers in non-agriculture, and (5) family / unpaid workers. 
International Standard Industrial Classification (ISIC) level. Some relevant statistics related to specific indicators of the creative economy could also be collected from gross value added, number of businesses, total employment and exports of creative economy. However, there is still little agreement on a methodology for measuring creative industries (UNCTAD, 2015; Joffe, 2012).

In the case of Indonesia, creative economy is officially measured by Badan Pusat Statistik (BPS), the national statistics agency of the Indonesian government. Measurements have been conducted twice, in 2016 and 2017. In 2016, a purposive survey was conducted with regard to creative economy, entitled Special Survey of Creative Economy (Survei Khusus Ekonomi Kreatif 2016) (BPS, 2017d), while in 2017 the creative economy was measured through the Economic Census (BPS, 2017a). The creative economy statistics resulting from Survei Khusus Ekonomi Kreatif 2016 and the Economic Census are publicly available on the website of Indonesia Creative Economy Board. ${ }^{2}$ They are also available as a printed version in BPS-Statistics Indonesia.

In Indonesia, as in the United Kingdom and Singapore, the five-digit International Standard Industrial Classification (ISIC) code is used for identifying creative economy activities. Indonesia has established its own creative economy ISIC codes, called Klasifikasi Baku Lapangan Usaha Indonesia (KBLI), Indonesia Standard Industrial Classification (ISIC) or KBLI-ISIC . As a definition of creative economy, Badan Pusat Statistik (BPS) - Statistics Indonesia, use the creative economy concept from UNCTAD (2015), which emphasizes four determinants of creative economy: creativity, heritage, economics and technology. Using these four determinants, BPS engaged with people in creative businesses in order to refine its information and understanding about creative economy activities, after which creative economy codes were extracted from the KBLI-ISIC, resulting in 223 creative economy codes out of the 1,573 five-digit Indonesia Standard Industrial Classification.

Creative economy in Indonesia is also measured and defined by 16 creative industries. Based on Presidential Decree Number 72, 2015 (Indonesia, 2015), creative economy in Indonesia covers 16 creative industries: (1) Architecture; (2) Interior design; (3) Visual communication design; (4) Product design; (5) Film, animation and video; (6) Photography; (7) Craft; (8) Culinary arts; (9) Music; (10) Fashion; (11) Application and game development; (12) Publishing; (13) Advertising; (14) Television and radio; (15) Performing arts; and (16) Fine arts. These 223 five-digit KBLI-ISIC are spread over the 16 creative industries and categories of International Standard Industrial Classification Revision 4 (DESA, 2008) which are presented in table 1:

Badan Ekonomi Kreatif Indonesia website is available from www.bekraf.go.id. 
Table 1. Number of five-digit creative economy KBLI

for each creative industry

\begin{tabular}{lllc}
\hline No. & \multicolumn{1}{c}{ Creative industries } & $\begin{array}{c}\text { ISIC Revision 4 } \\
\text { category/section }\end{array}$ & $\begin{array}{c}\text { KBLI-ISIC } \\
\text { number }\end{array}$ \\
\hline 1 & Architecture & M & 2 \\
2 & Interior design & M, P & 2 \\
3 & Visual communication design & M, P & 2 \\
4 & Product design & M, N, P & 3 \\
5 & Film, animation and video & C, J, P & 9 \\
6 & Photography & M, P, R & 7 \\
7 & Craft & C, G & 72 \\
8 & Culinary arts & C, G, I & 32 \\
9 & Music & $\mathrm{C}, \mathrm{G}, \mathrm{J}, \mathrm{N}, \mathrm{P}, \mathrm{R}$ & 9 \\
10 & Fashion & $\mathrm{C}, \mathrm{G}, \mathrm{P}$ & 19 \\
11 & Application and game developer & $\mathrm{J}, \mathrm{M}, \mathrm{R}$ & 13 \\
12 & Publishing & $\mathrm{C}, \mathrm{G}, \mathrm{J}, \mathrm{M}, \mathrm{R}$ & 17 \\
13 & Advertising & $\mathrm{M}$ & 5 \\
14 & Television and radio & $\mathrm{J}$ & 5 \\
15 & Performing arts & $\mathrm{N}, \mathrm{P}, \mathrm{R}$ & 10 \\
16 & Fine arts & G, M, P, R & 16 \\
& Total & & 223 \\
\hline
\end{tabular}

Source: DESA (2008) and BPS (2016f).

Note: Category/section in ISIC Revision 4 for Creative Economy

C. Manufacturing

G. Wholesale and retail trade; repair of motor vehicles and motorcycles

I. Accommodation and food service activities

J. Information and communication

M. Professional, scientific and technical activities

N. Administrative and support service activities

P. Education

R. Arts, entertainment and recreation

Based on the creative economy KBLI-ISIC codes, the measurement of creative economy in Indonesia has been implemented through the Special Survey of Creative Economy (Survei Khusus Ekonomi Kreatif) (BPS, 2016e) by applying the nonprobability sampling method - purposive sampling - due to the unavailability of an existing sampling frame on creative economy. Purposive sampling was applied by choosing, as the unit sample, businesses which fulfill the following criteria: (i) The businesses are matched with one or more of the 223 creative economy KBLI-ISIC; 
and (ii) the nature of the businesses' activities are indicative of creative concept, such as creativity, heritage, economics and technology. The number of samples in the Survey was selected based on these two criteria, and therefore businesses outside the two criteria will be excluded.

As non-probability sampling was used in the Survey, the results were not estimated for the overall population, but became the profile of creative businesses. Some information was collected through the Survey, such as the number of businesses engaging in the creative economy sector, gross revenue in creative economy businesses and total employment in creative economy businesses.

The other macroeconomic indicators in creative economy were also presented in 2016, namely export of creative products (BPS, 2016b), creative workers (BPS, 2016d) and gross domestic product of the creative economy (BPS, 2016c). Each indicator has its own methodology in which to arrive at an estimated value.

Furthermore, current measurement of the Indonesian creative economy in 2017 utilized results from the Economic Census, and the methodology was improved by basing the sampling frame on it. The frame was developed by matching the creative economy KBLI-ISIC codes with businesses in the economic census frame. In this case, it was found that the total number of creative economy businesses in Indonesia was about 8.2 million, and this became the framework for creative economy measurement. Based on this framework, a study was conducted to identify some characteristics of a creative economy business profile, such as: (1) gender of employer; (2) start-up businesses; (3) entity (legal) status; (4) preparation of financial reports; (5) business's network; (6) employment; (7) internet presence; (8) engagement in e-commerce; (9) franchise status; and (10) gross revenue.

Based on Indonesian experience, it is important to formulate the process by which to standardize measurement of the creative economy. In this paper, we make some effort to document the processes for measuring creative economy in Indonesia as shown in figure 1. 


\section{Figure 1. Process for measuring creative economy in Indonesia}

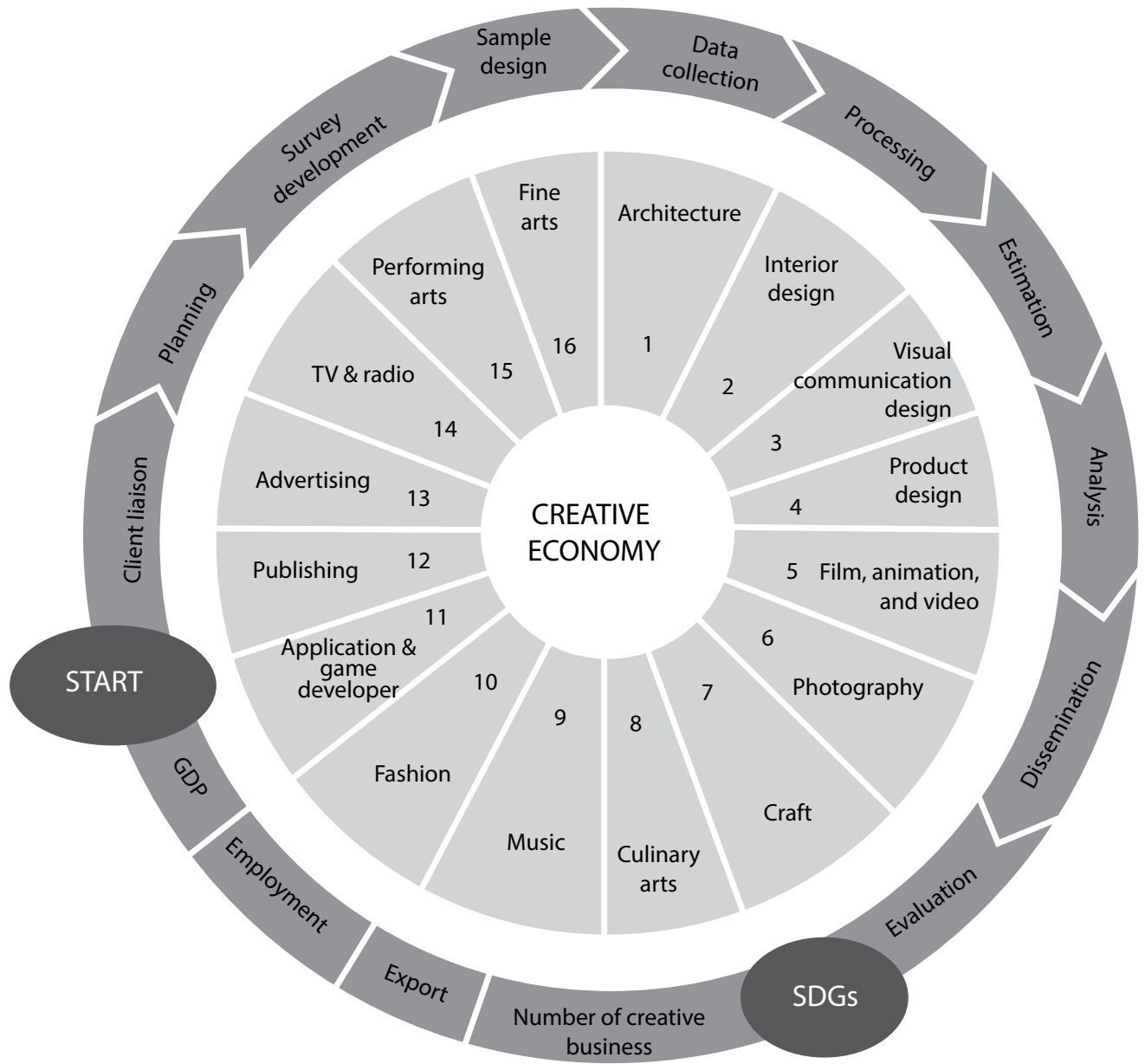

Goal 1 Eradicate extreme poverty for all people everywhere

Indicator 1.2.1 Proportion of population living below the national poverty line, by sex and age

Goal 8 Promote sustained, inclusive and sustainable economic growth, full and productive employment and decent work for all 
1) Indicator 8.1.1 Annual growth rate of real GDP per capita

2) Indicator 8.3.1 Proportion of informal employment in non-agriculture employment, by sex

3) Indicator 8.9.2 Number of jobs in tourism industries as a proportion of total jobs and growth rate of jobs, by sex.

Goal 9 Build resilient infrastructure, promote inclusive and sustainable industrialization and foster innovation

1) Indicator 9.5.1 Research and development expenditure as a proportion of GDP

2) Indicator 9.5.2 Researchers (in full-time equivalent) per million inhabitants

Figure 1 describes creative economy coverage and the phase of data collection for measuring creative economy in Indonesia. The 16 Indonesian creative economy industries are measured using a standard survey life cycle, which starts from client liaison, planning, survey development, sample design, data collection, processing, estimation, analysis, dissemination and evaluation. The resulting data collection is beneficial for describing the creative economy's contribution to sustainable development, particularly in supporting Sustainable Development Goals 1, 8 and 9. However, this approach is still not standardized, particularly regarding the determination of concept definitions for the 16 Indonesian creative economy activities.

Some of the creative economy insights emerging from the Special Survey of Creative Economy (Survei Khusus Ekonomi Kreatif) (BPS, 2016f) could support the improvement of SDGs indicator 1.2.1 "proportion of population living below the national poverty line, by sex and age", specifically:

a) The number of creative economy businesses in Indonesia in 2016 is 8.2 million.

b) The majority of creative economy entrepreneurs are women (55 per cent).

c) Small and microbusinesses are an important part of the creative economy in Indonesia. Almost 92 per cent of creative industries in Indonesia are from small or microestablishments - Usaha Mikro Kecil.

d) The average educational attainment of creative economy entrepreneurs is post-secondary education. 
This data can be related to SDG indicators to show how improvement in the creative economy can raise the standard of living in the general population.

Other creative economy data arising from the Indonesia Economic Census 2016 (BPS, 2017a) may be connected to three SDG indicators: Indicator 8.1.1 (Annual growth rate of real GDP per capita); Indicator 8.3.1 (Proportion of informal employment in non-agriculture employment, by sex); and Indicator 8.9.2 (Proportion of jobs in sustainable tourism industries out of total tourism jobs). Some of the data relating to these indicators are as follows: ${ }^{3}$

a) The proportion of start-up businesses in the creative economy is 19.8 per cent.

b) The number of creative economy businesses in Indonesia in 2016 was 8.2 million.

c) The creative economy of Indonesia is driven by three dominant industries: Culinary arts, fashion, and arts and crafts (Kriya).

d) Most (92.6 per cent) creative economy businesses have revenues under 300 million rupiah per annum $(\$ 20,690)$.

e) The majority of businesses in creative economy tend to be microenterprises, with 1-4 employees (95.6 per cent).

f) The contribution of the creative economy towards national GDP in 2016 was 7.4 per cent (BPS, 2017c).

This data can be related to the three SDG indicators which suggest that development of creative economy will raise the per capita GDP, absorb a greater number of informal employees, and generate more jobs in creative fields.

Other creative economy data which may be connected to SDG Indicator 9.5.1 (research and development expenditure as a proportion of GDP) is as follows:

a) The creative industries conducting research and development are application and game development (51.4 per cent), television and radio (46.2 per cent) and visual communication design (44.9 per cent).

b) The contribution of creative economy to GDP in 2016 was 922.6 trillion rupiah ( $\$ 63.6$ billion) (BPS, 2017c).

c) The influence of the creative economy was felt mainly in the domestic market. Overseas sales accounted for only 8.4 per cent of total output, whereas export of creative economy commodities in 2016 was $\$ 20$ billion (BPS, 2017b).

Exchange rate of 1 United State dollar to 14,500 Indonesian rupiah, as of December 2018. 
This data can be related to SDG indicators to clarify that creativity is a driver of innovation. Improving creativity can thus encourage innovation in general, and specifically research and development.

\section{ISSUES AND CHALLENGES}

The measurement of creative economy is generally challenging - not just in Indonesia - and establishing a benchmark to measure creative economy is still problematic due to a range of categorization issues, both conceptual and practical. In recent years, many agencies and governments have put much effort into collecting data on the creative economy (WIPO, 2013). Creative economy data collection has been conducted twice in Indonesia: the Creative Economy Survey in 2016, and from the Economic Census in 2017.

Sample numbers in the 2016 Creative Economy Survey are 6,000 businesses from 16 creative industries in 57 cities and districts in 34 provinces of Indonesia, while in 2017, the compilation of creative economy data utilized 2016 Economic Census data (BPS, 2017a). The 2016 Economic Census covered all businesses in all sectors of the Indonesian economy, except the agricultural sector (KBLI-ISIC category A), government administration sector (KBLI-ISIC category $O$ ) and household activities as employer sectors (KBLI-ISIC category T).

The issues and challenges in creative economy data collection in Indonesia can be summarized based on our experience in 2016 and 2017 as presented below:

\section{Lack of standardized definition}

Development of the creative economy has been hampered by multiple definitions and the lack of a consistent approach on how to classify creative activity. The first limitation is the definition of creative economy itself. At an early stage of defining creative economy industrial classification codes (KBLI-ISIC), the National Statistics Office of Indonesia discussed with the Creative Economy Agency of Indonesia (Badan Ekonomi Kreatif) and people working in creative businesses how to receive more information and refine the definition of creative economy generally, and also creativity in each sector. The very intangibility of creativity requires the application of strict criteria for measurement. Each business's criteria of what it means to be creative must be precisely defined in order to delineate which workers and activities can be classified as creative. This process of classification was also evident in the fastchanging communication, cultural and content industries. The fluidity of definitions further complicates understanding and measurement of creative economy. In future, the KBLI could be revised to take account of developments in creative industries, but at present creative economy classification still differs among countries, and international standards and definitions are not yet available. 


\section{No sampling frame}

Generating statistics of creative economy is still new for Indonesia, and the quality of statistics is dependent on the availability of a reliable sampling frame. This issue was addressed in 2016, when Statistics Indonesia conducted a Creative Economy Survey 2016 (BPS, 2016f) in 34 provinces. The sample selection was solely based on non-probability sampling, due to the unavailability of a framework for creative economy businesses in 2016.

In Indonesia, the framework was based on the Economic Census 2016, which identified the businesses matching 223 five-digit classifications in KBLI-ISIC. However, the list of creative economy businesses in the Economic Census frame is quite volatile, due to the lack of standardization of concept and definition in the creative economy KBLI-ISIC codes.

\section{Creative industry classification does not correspond well to the standard creative industries.}

With a standard industrial classification approach, one of the issues is that KBLIISIC codes can be relevant across many creative industries. Within the 223 five-digit KBLI-ISIC codes, there are 14 codes that belong to more than one creative industry, as shown in table 2.

Indicators of creative economy in Indonesia are based on 16 creative industries, with some limitation of statistics due to lack of standardization in the concept and methodology.

\section{Challenges}

All of the creative economy measurements have been based on the industrial classification approach, using the 223 five-digit KBLI-ISIC in creative economy, but despite this, more creative people work outside the creative industries than within them. One of the challenges in measuring creative economy in Indonesia is using a variety of approaches, such as occupation data. The disaggregation of creative economy data is also challenging, as it is necessary to extrapolate statistics based on geographic area, urban-rural classification, the 16 creative industries, gender and other socioeconomic indicators.

These issues and challenges imply that the approach of measuring creative economy needs to be broad, and that data collection must be standardized across all countries, so as to ensure a sustainable database for supporting the SDGs. 


\section{Table 2. Five-digit KBLI-ISIC code crosses with more than one creative industries}

\begin{tabular}{|c|c|c|c|}
\hline No & Codes & Title & Creative industries \\
\hline 1 & 58200 & Publishing software & $\begin{array}{l}\text { - Application and game developer; } \\
\text { - Publishing }\end{array}$ \\
\hline 2 & 59202 & $\begin{array}{l}\text { Music publishing activity and } \\
\text { music books }\end{array}$ & $\begin{array}{l}\text { - Music; } \\
\text { - Publishing }\end{array}$ \\
\hline 3 & 70203 & Public relation activity & $\begin{array}{l}\text { - Advertising; } \\
\text { - Fine arts }\end{array}$ \\
\hline 4 & 70204 & $\begin{array}{l}\text { Investment consulting activities and } \\
\text { futures trading }\end{array}$ & $\begin{array}{l}\text { - Application and game developer; } \\
\text { - Fine arts }\end{array}$ \\
\hline 5 & 70209 & $\begin{array}{l}\text { Consultation activities other } \\
\text { management }\end{array}$ & $\begin{array}{l}\text { - Advertising; } \\
\text { - Fine arts }\end{array}$ \\
\hline 6 & 74100 & Special design activities & $\begin{array}{l}\text { - Interior design; } \\
\text { - Communication visual design; } \\
\text { - Product design }\end{array}$ \\
\hline 7 & 85420 & Cultural education & $\begin{array}{l}\text { - Photography; } \\
\text { - Performing arts; } \\
\text { - Music; } \\
\text { - Fine arts }\end{array}$ \\
\hline 8 & 85497 & Private technical education & $\begin{array}{l}\text { - Interior design; } \\
\text { - Communication design visual; } \\
\text { - Product design }\end{array}$ \\
\hline 9 & 85499 & Other private education & $\begin{array}{l}\text { - Movies, animations, and videos; } \\
\text { - Fashion; } \\
\text { - Performing art; } \\
\text { - Fine art }\end{array}$ \\
\hline 10 & 90002 & Art workers' activities & $\begin{array}{l}\text { - Photography; } \\
\text { - Music; } \\
\text { - Application and game developer; } \\
\text { - Performing arts; } \\
\text { - Fine arts }\end{array}$ \\
\hline 11 & 90006 & Arts facility operational activities & $\begin{array}{l}\text { - Photography; } \\
\text { - Performing arts }\end{array}$ \\
\hline 12 & 90009 & $\begin{array}{l}\text { Activities entertainment, arts and } \\
\text { other creativity }\end{array}$ & $\begin{array}{l}\text { - Photography; } \\
\text { - Performing arts }\end{array}$ \\
\hline 13 & 91021 & Government-managed museum & $\begin{array}{l}\text { - Photography; } \\
\text { - Fine arts }\end{array}$ \\
\hline 14 & 91022 & Privately-managed museum & $\begin{array}{l}\text { - Photography; } \\
\text { - Fine arts }\end{array}$ \\
\hline
\end{tabular}

Source: Indonesia, Badan Pusat Statistik (2016a). 


\section{CONCLUSION}

This paper has sought to highlight some of the issues and challenges faced by Indonesia in measuring creative economy, and utilizing that measurement to support SDGs. Based on this goal, it may be concluded that:

(a) Creative economy contributes to sustainable development, which can be seen particularly in the Sustainable Development Goals 1, 8 and 9.

(b) Creative economy in Indonesia is officially measured by National Statistics Office of Indonesia. This measurement has been conducted twice, in 2016 and 2017. Five-digit Indonesia Standard Industrial Classification Codes (KBLI) of creative economy, built by Indonesia, were used as the key for identifying creative businesses. There are 223 five-digit KBLI-ISIC of creative economy in Indonesia.

(c) Establishing a benchmark to measure the creative economy is problematic. Some of the issues are lack of standardized definitions for creative economy, no sampling frame and creative industry classification (KBLI codes) that do not correspond well to standard creative industry criteria.

Other challenges to measuring creative economy in Indonesia are using a different basis, such as occupation, and disaggregation of data based on geographic area, urban-rural, 16 industries of creative economy, gender and other indicators.

Despite many issues and challenges, measuring creative economy remains important to economic development in Indonesia. Indonesia will continuously improve the provision of creative economy data, as a benchmark to support the Sustainable Development Goals. 


\section{REFERENCES}

Indonesia (2015). Presidential Decree Number 72. Jakarta.

Indonesia, Statistics Indonesia, Badan Pusat Statistik (BPS) (2016a). Report on Analysis of Classification of Creative Economy Activities in KBLI 2015. Jakarta.

(2016b). Report on Analysis of Creative Economy Export in 2010-2015. Jakarta.

(2016c). Report on Analysis of Creative Economy GDP in 2010-2015. Jakarta.

(2016d). Report on Analysis of Creative Economy Workforce in 2010-2015. Jakarta.

(2016e). Report on Analysis of Harmonization of KBLI 2015-HS 2012 for 16 (Sixteen) Industries Creative Economy. Jakarta.

(2016f). Report on Creative Economy Business Profile 2016 based on SKEK 2016. Jakarta.

(2017a). Report on Creative Economy Business Profile in 16 Creative Economy Industries Based on Economic Census 2016 (SE2016). Jakarta.

(2017b). Report on Creative Economy Export in 2010-2016. Jakarta. Available from www. bekraf.go.id/pustaka/page/24-ekspor-ekonomi-kreatif-2010-2016.

(2017c). Report on Creative Economy GDP in 2014-2016. Jakarta. Available from www. bekraf.go.id/pustaka/page/67-laporan-penyusunan-pdb-ekraf-5-provinsi-2010-2016menurut-lapangan-usaha.

(2017d). Report on Creative Economy Workforce in 2010-2016. Available from Available from http://www.bekraf.go.id/pustaka/page/55-tenaga-kerja-ekonomi-kreatif-2011-2016.

Joffe, Avril (2012). Policy-making for the creative and cultural industries. Presentation to UNESCO Capacity Building Program - Africa.

Lestariningsih, E., S. Gusnisa, and K. Maharani (2017). Legal setting for the development of interagency sectoral statistics database (ISSD). Paper presented at Asia-Pacific Economics Statistics Week, 22 - 26 May 2017. BPS-Statistics Indonesia. Available from https://drive.google.com/file/d/OByEfoVVpdu29NE5iS3BpYi1WTTg/view.

United Kingdom, Department for Digital, Culture, Media and Sport (DCMS) (2001). Creative Industries Mapping Documents. United Kingdom: DCMS. Available from https://assets. publishing.service.gov.uk/government/uploads/system/uploads/attachment_data/ file/183544/2001 part1-foreword2001.pdf.

United Nations, Department of Economic and Social Affairs (DESA) (2008). International Standard Industrial Classification of All Economic Activities Revision 4. New York. Available from https://unstats.un.org/unsd/publication/seriesm/seriesm_4rev4e.pdf.

United Nations Conference on Trade and Development (UNCTAD) (2010). Creative Economy Report 2010: A Feasible Development Option. Geneva. Available from https://unctad. org/en/pages/PublicationArchive.aspx?publicationid=946

(2015). Creative Economy Outlook and Country Profiles: Trends in International Trade in Creative Industries. Geneva. Available from https://unctad.org/en/PublicationsLibrary/ webditcted2016d5_en.pdf.

(2018). UNCTAD's work on the Creative Economy. Available from https://unctad.org/en/ Pages/DITC/CreativeEconomy/Creative-Economy.aspx. 
United Nations Development Programme (UNDP) (2015). Report on Indicators and Data Mapping to Measure Sustainable Development Goals (SDGs) Targets: Case of Indonesia 2015. Jakarta. Available from www.id.undp.org/content/indonesia/en/home/library/environment_energy/ indicators-and-data-mapping-to-measure-sustainable-development-g.html.

United Nations Development Programme (UNDP), and United Nations Educational Scientific and Cultural Organization (UNESCO) (2013). Creative Economy Report 2013 Special Edition: Widening Local Development Pathways. New York: UNDP and UNESCO. Available from www.unesco.org/culture/pdf/creative-economy-report-2013.pdf.

World Economic Forum (2016). White Paper: Factors for Enabling the Creative Economy. Geneva. Available from www3.weforum.org/docs/WEF_2016_WhitePaper_Enabling_ the_Creative_Economy.pdf.

World Intellectual Property Organization (WIPO) (2013). Study on the Economic Contributions of Copyright and Related Rights Industries in Indonesia. Geneva. Available from www. wipo.int/export/sites/www/copyright/en/performance/pdf/econ_contribution_cr_id.pdf. 